\title{
Improving the methodological tools for assessing the contribution of the innovation and investment component to increase the cost of high-tech business
}

\author{
Yury Doroshenko ${ }^{1, *}$, Irina Malykhina ${ }^{1}$, and Irina Somina $^{1}$, and Maria Starikova ${ }^{1}$ \\ ${ }^{1}$ Belgorod state technological University named after V.G. Shukhov, 46, Kostyukova street, 308012, Belgorod, Russia
}

\begin{abstract}
Relevance of the research topic is due to the specificity and growing strategic importance of the development of high-tech industry, the production of high-tech products, as well as the desire of business owners to constantly increase its value. The main problems and prospects for the intensification of innovation in terms of its impact on the speed and quality of its development are reviewed. The essential characteristics of innovation and investment activity are analyzed, the progressiveness of the stages of functioning of the subjects of the innovation and investment process, united by a common goal, is revealed. Contributed by the author to the definition of high-tech business. Analyzed the main methodological approaches to assessing the value of the business. The factors that have the greatest influence on the formation of conditions for increasing the cost of high-tech business have been studied. The methodological tools for assessing the contribution of the innovation and investment component to the increase in the value of the high-tech business have been improved. The nature of the relationship and interdependence of two types of activity: innovation and investment, as well as opportunities for the development of high-tech business and the growth of its value are analyzed.
\end{abstract}

\section{Introduction}

The Russian economy in modern conditions has to face many challenges. Thus, the complexity of the geopolitical situation, the sanctions pressure, the restriction of foreign investment inflows, high competition in the high-tech products market aggravated the crisis in the economy and led to a decrease in the business value of domestic companies, including the high-tech sector of the economy.

At present time it is necessary to provide the viability and efficient operation of companies in the high-tech sector of the economy using the innovation and investment orientation of the development strategy and tactics with the aim of enhancing competitive advantages and increasing the value of the business as a whole.

Innovation, as the most effective way to intensify the reproductive processes, is the source of the increment of value added. According to scientists, innovations are such a sphere the investment of which ensures the creation of a high-tech economic structure, the development and introduction of new technologies, the production and export of competitive products with high added value. But the high rates and efficiency of economic development are justified not only by the amount of invested capital, but also by its quality, ensured by innovation [1].

It was necessary to develop the economy in general and business entities in particular, the inflow of financial resources to create new and modernize existing industries, develop new equipment and technologies to saturate the consumer market with high-demand and high-tech goods and services. This will allow one to generate income and achieve the main goal - to achieve and ensure socioeconomic well-being and sustainable development of a society based on the latest knowledge and high technologies. Domestic and foreign scientists attribute the following resources to investment [1]:

- monetary resources;

- bank deposits;

- divvies;

- shares;

- technology;

- cars;

- equipment;

- patents;

- licenses;

- loans;

- property and non-property rights, including intellectual and industrial property.

The resources described above are investments by their nature that can be valued in terms of value and affect the value of a high-tech business.

We have to note the high-tech sector of the economy characterized by the involvement of highly qualified specialists, investment resources, the use of critical technologies, which are technologies that are interdisciplinary in nature. They create an instrument for

\footnotetext{
* Corresponding author: 549709@mail.ru
} 
the qualitative development of many technological areas or areas of research and development and give, in aggregate, the main contribution to solving the key problems of the priority directions in the development of science and technology. The formation and application in the real sector of the economy of critical technology provide a decisive contribution to the achievement of specific goals in the field of national security, the economic and social development of the country, the effective functioning of individual sectors of industrial production [2].

Connection of innovation and investment activity is an indisputable fact, confirmed by the very nature of the occurrence of these processes, as a result of which the term "innovation and investment" is used in the scientific literature, indicating a close relationship. We emphasize that innovation creates the prerequisites for attracting investment, and investment is the catalyst for research and development. Thus, the formation of an effective mechanism for financing scientific research, which results in innovations and high technologies, should be aimed at integrating the results of scientific and technological progress related to the continuous improvement of the structure of social production.

So we can conclude that the innovation and investment component, which provides a qualitative level of development of business entities including hightech companies is a single interconnected system. Innovations provide a high level of investment quality, which has a positive effect on the cost of high-tech businesses.

\section{Method}

Main methodological and methodological approaches used in the study of problems and prospects of innovation and investment development of high-tech business were worked out by foreign and domestic authors, namely P. Drucker, R. Cantillon, A. Marshall, J. Schumpeter, G. Markovits, N.D. Kondratieva, S.Yu. Glazyev, V.Ya. Gorfinkel, M.A. Bendikova, I.E. Frolova, A.I. Tatarkina, O.A. Romanova, V.V. Akberdina, G.I. Latyshenko and others. The conceptual aspects of the formation of new industrialization, as a separate type of social transformations based on innovations, were first described in the works of $\mathrm{J}$. Galbraith. They were effectively reflected in the concepts of D. Bell's post-industrial society and E. Toffler's super-industrial civilization, as well as in the works of A.A. Bogdanova, A.V. Zvereva, J. Van Dein, N.D. Kondratiev, B.N. Kuzyka, G. Mensha, S. Kuznetsova, E. Toffrera, H. Freeman, Yu.V. Yakovets. They laid the foundations of the theory of value and tried to define its epistemological sources by such distinguished economists as W. Petit, A. Smith, D. Ricardo, T. Malthus, J. S. Mill, A. Marshall, K. Marks, and others. An alternative approach to return on equity, called the model for assessing the profitability of financial assets, was developed by W. Sharp, J. Lintner and J. Mossin. The methodology for estimating the value of a company was formed by M. Gordon and A. Shapiro and was based on a model for calculating the value of the share capital.

\section{Main part}

High-tech companies are commercial subjects of economic relations, the main production of goods, works, services of which is innovative. At the same time, the main production of goods and services of these companies, as a special type of organization, is innovative and meets the following criteria [2]:

1. The key for achieving success of a high-tech company is not only its ability to offer fundamentally new products and services on the market, but also the harmonization of its business goals with the strategic interests of the state in the field of industrial and trade policies.

2. The level of knowledge-intensiveness, which is defined as the share of research and development costs related to the results of production, used by companies in their production of technologies - not less than 3.5\%.

3. Main technology used by the company in its production is included in the current national "List of Critical Technologies" at the time of introducing its goods or services onto the market.

Thus, high-tech companies in their activities are based on the results of innovation. They are strategic participants in market relations, supplying products that often have unique properties and satisfy dynamically changing market needs [3].

Domestic and foreign scientific literature pays a lot of attention to the problem of improving the methodological approaches to the valuation of companies and the high-tech sector. This problem reflects the real concern of business owners interested in ensuring a stable, constant increase in the value of companies. Successful business is based on a clear understanding of all business processes, an analysis of the strengths and weaknesses of the company and the constant monitoring of the position among competitors. One of the most important indicators of the success of a company is its value, since it determines the income. At the same time, the contribution of the innovation and investment component to the achievement of the goal is quite significant. However, it is necessary to consider the main methodological approaches to assessing the value of a business. Evaluation of the company allows you to determine its current market capitalization. For the owners of the company, this procedure provides an opportunity to assess the quality of business, to identify strong and weak areas of activity. For third parties, this assessment allows you to determine the attractiveness of investments in this company [4].

Methods of business valuation have a wide practical application and are actively used by the most successful companies. They can be used by any organization to assess the value of their own business, analyze the possibilities of eliminating problem business processes and develop strategies for increasing market value. To date, such classical methods of business valuation are being actively studied and used: 
1. Income approach [5]: determining the value of a business based on consideration of cash flows over the period of operation of the business unit. The cost of a business is calculated from the sum of discounted cash flows and the terminal value of the company, which is calculated in the same way as an infinite sequence of equal payments made at regular intervals, so the valuation of the business $\mathrm{C}(\mathrm{p})$ comes to the definition of net income calculated on the date of valuation:

$$
\mathrm{C}(\mathrm{p})=(1-ц) * \mathrm{VPt}+ц * \mathrm{SP},(1)
$$

where $\longleftarrow$ is the probability of business survival;

SPT - the cost of the flow of net cash income from the sale of products, indicated on the valuation date of the enterprise, monetary units of measurement;

VPt - the residual value of the enterprise at the end of the billing period, indicated on the valuation date of the enterprise, monetary units of measurement.

Business valuation, reflecting usage rights, is based on three main principles:

- the owner will not sell the company at a price lower than the value of the future net income projected at the time of sale;

- the value of the enterprise depends on the size and distribution in time of the net income that the investor will receive during the period of operation of the enterprise, all other things being equal;

- the potential buyer will not pay for the share in the enterprise more than the sum of the future net incomes expected by the years of operation, given at the time of the sale of the enterprise.

The residual value of the business is determined by the Gordon model:

$$
\mathrm{VPt}=\mathrm{AFt} *(1+\mathrm{g}) /(\mathrm{rt}+\mathrm{g})
$$

where VPt is the residual value of the enterprise at the end of the billing period units;

$\mathrm{t}$ - the current year of the settlement period;

$\mathrm{AFt}$ - depreciation in the last year of the forecast, monetary units;

$\mathrm{Rt}$ - the discount rate per year;

$\mathrm{g}$ - the growth rate of assets used to save the business.

The cost of the flow of net income from sales of products $(\mathrm{SPt})$ is determined by the formula:

$$
\mathrm{sPt}=\mathrm{X} \mathrm{CF}(1+\mathrm{rt})^{\prime},
$$

$\mathrm{t}=1$

where CFt - debt free cash flow in year $\mathrm{t}$; $t$ is the current year of the settlement period; $\mathrm{T}$ - the final year of the settlement period; $\mathrm{rt}$ - discount rate per year $\mathrm{t}$;

Then the expanded formula (1) takes the form:

$$
\mathrm{C}(\mathrm{p})=(1-ц)^{*} \mathrm{Aft}^{*}(1+\mathrm{g}) /(\mathrm{rt}+\mathrm{g})+\mathrm{X} Ц * \mathrm{CFt} /(1+\mathrm{rt}) \mathrm{t},
$$

$\mathrm{t}=1$

where ц - the probability of business survival;

AFt - depreciation in the last year of the forecast, monetary units of measurement;

$\mathrm{g}$ - growth rate of assets used to save the business;
CFt - debt free cash flow in year $t$;

$\mathrm{T}$ - the period of the forecast of receiving net income (the period of the predicted operation of fixed assets of the enterprise), years.

Forecasting cash flow for high-tech enterprises is assumed to be equal to the period of updating the basic technologies. In domestic and foreign practice, the most common in assessing high-tech companies is the income approach, since the value of a company is primarily determined by its ability to generate income in the future.

2. Comparative [6]: based on the application of the method of multipliers (price - profit, price - cash flow, price - dividends, price - sales revenue, price - book value). The procedure for using this method consists of three main steps:

- Definition of many companies-analogues.

- Selection from the considered set of suitable companies.

- Drawing up a list of 3-5 similar companies for calculating multipliers.

3. Costly [7]: it is usually used to estimate the controlling stake of a current company and includes consideration of the company's value in terms of the costs incurred by subtracting the cost of attracted capital from the market value of the assets. When using the cost method, the assessment is performed using steps such as [6]:

- assessment of industrial real estate;

- evaluation of production equipment;

- assessment of net assets;

- evaluation of financial investments;

- assessment of the liquidation value;

- valuation of intangible assets.

However, in a conceptual sense, scientists distinguish between the concept of "high-tech business" and an enterprise, an organization as a "property complex", believing that a business is an enterprise in operation. And its value exceeds the value of the property complex by the amount of intangible assets caused by the influence of such factors as personnel, own technologies, established corporate culture, etc. At the same time, a business may act as a specific product [8].

Taking into account the complexity and versatility of the business valuation methodology, we consider it expedient to supplement the methodological approaches to assessing the contribution of the innovation and investment component to the business value growth of the high-tech sector with a number of key characteristics that take into account the organization's ability of:

- effective response to changing environmental conditions;

- building and strengthening innovative and investment potential;

- the possibility of attracting investment for the implementation of innovative projects;

- the ability to realize their potential value as a portfolio of assets;

- the influence of non-financial factors in the creation of a new value with a multiplier effect;

- increase in brand value;

- strengthening of image positions. 
At the same time, when applying the cost method of estimating the value of high-tech companies, we consider it expedient to supplement the existing procedures, which form it, with an assessment of the economic efficiency of innovative projects being implemented. However, it is worth making a risk adjustment in the implementation of high-tech projects, especially if there are several, taking into account when calculating the beta coefficient as a cumulative measure of risk that assesses the risks of investing in an innovative project, taking into account objective market reactions.

\section{Conclusion}

Nowadays the success of the economic development of the state can be achieved only with the development of an innovative economy that is being formed on the basis of the latest knowledge and high technologies. The speed, quality and prospects for the implementation of the innovation process, the development of science, technology and technology form the basis for the development of high-tech business, create an opportunity to strengthen the competitive advantages of high-tech business entities, provide the ability to produce high-tech products that meet the highest international standards.

The high technologies sphere is one of the most significant in the modern world economy. The main competitive advantage of high-tech companies is the rapid and successful introduction of high-quality and popular innovations to the world market. Thus, the growth in demand for products of high-tech industries for the year was recorded for the first time since 2012:+ $2.4 \%$ by $2017,+6.6 \%$ in December 2018 compared to December 2017 [9, 10].

Conscious necessity of the real sector of the economy in the implementation of the results of innovation activities, the implementation of orders for individual research to modernize production are a tool for attracting investment and the most important source of economic development, which reflects the contribution of innovation and investment activity to the growth of value of high-tech business companies. However, the effectiveness of this process is possible with the consolidation of efforts of all participants in economic relations, while ensuring the successful implementation of investment activities, in particular, the mobilization of financial, material, human, informational, managerial, legal and other resources.

In conclusion, we may say the maximum value of the company, taking into account internal and external improvements, is the optimal restructured value. The difference between this value and the market value of the company is the value characterizing the value that must be created by the management efforts through the implementation of the innovation and investment component.

\section{Findings}

Summing up the main results, we may say:

1. A high-tech company is a commercial enterprise whose main goal is to create a unique product and service, which, due to the exclusivity of its products, needs to create new, unparalleled submarkets in previously formed industries.

2. In assessing the value the concept of "high-tech business" is delimit the concept from the organization as a "property complex".

3. A profitable business valuation method is most preferable if the company has a permanent capital structure and is present in the market for a long period of time.

4. Using of the valuation method is determined by the specific situation, the availability of data, but the method of discounting cash flows in the framework of the income approach is used as the main one.

5. Evaluation of the company allows you to determine its current market capitalization.

The article was prepared during implementation of project No 26.9642.2017/8.9 within the framework of the State task of the Ministry of Education and Science of Russia.

\section{References}

1. K. Gluharev, Proceedings of the Russian State Pedagogical University named after A.I. Herzen 97, 92-97 (2009).

2. A. Laptev, Innovations 7(105), 35-41 (2007).

3. Y. Doroshenko, I. Somina, I. Malykhina, International Journal of Pharmacy \& Technology 8(4). 26664-26670 (2016).

4. Y. Doroshenko, I. Somina, I. Malykhina, Advances in Economics, Business and Management Research 61, 66-70 (2018).

5. B. Gusakov, Bulletin PSTU. Social and Economic Sciences 13(37), 65-73 (2012).

6. A. Trusova, A. Trusov, A. Duzheva, A. Ilyina, Fundamentals of Economics, Management and Law 4(16), 147-149 (2014).

7. O. Askanova, A. Karpenko, Society: politics, economics, law 2, 38-42 (2010).

8. V. Katsman, I. Kosorukova, A. Rodin, Evaluation activity. Legal, theoretical and mathematical foundations: studies. manual (M.: Market DS, Moscow, 2008).

9. Institute of the problems of natural monopolies.Retrieved from http://www.ipem.ru/news/ipem/1663.html (2018).

10. Strategy of innovative development of the Russian Federation for the period up to 2020. Approved Decree of the Government of the Russian Federation from 8th of December, № 2227-p. Retrieved from http:/government.ru/docs/9282/

(2011). 